\title{
Palliative, palliative or palliative?
}

\author{
René Robert ${ }^{1 *}$ (D) and Michel Goldberg ${ }^{2}$
}

\section{Introduction}

Palliative care has emerged as a crucial component in the medical course of many patients, particularly in cancer, neurodegenerative diseases, advanced heart, respiratory or liver failure $[1,2]$. However, the single word "palliative" is uniformly used, whatever the stages of disease evolution, and the specific therapeutic avenues that may remain possible. In case of acute altered organ function, the palliative patient "label" can lead to therapeutic withholding or withdrawal of life support strategies, at times even entailing refusal of ICU admission. It would make sense to use more nuanced and discriminating terminologies to clarify different clinical situations.

\section{The same word covers three different stages of the disease}

The term "palliative" reflects a clinical situation without prospect of complete recovery from the illness. It is defined as treatment that alleviates the symptoms of a disease without acting on its causes. Palliative care integrates the management of physical and psychological pain and other symptoms that are bothersome to the patient. In several clinical situations, it begins early in the patient's life when his prognosis is still good; this initial stage implies prolonged life expectancy and normal or sub-normal quality of life (QOL). At a latter stage, the end of life is approaching. Physical condition is altered, activities are reduced and the patient may need partial assistance with some daily living activities. Mental capacities are generally close to normal. QOL is limited but may still be considered acceptable based on the patient's self-evaluation. At this stage of the disease, curative care

\footnotetext{
*Correspondence: rene.robert@chu-poitiers.fr

${ }^{1}$ Service de Médecine Intensive Réanimation, University of Poitiers, CHU Poitiers France, CIC Inserm 1402 CHU, 86000 Poitiers, France

Full list of author information is available at the end of the article
}

is reaching the end of its intended effect and the palliative care has increased [3]. Lastly, when the end of life is near, physical capacities are extremely poor, QOL is deeply altered and the patient needs assistance with all daily living activities. Overall distinction between these three stages is associated with prognosis of diseases, comorbidities, QOL evaluation. However, the boundary between the different stages is not clear, and healthcare teams need to decipher the grey areas between them.

Taking the three stages of the patient's course outlined above, we can schematically define an appropriate management strategy. During the first phase, the patient should be considered as unrestricted and benefit from unlimited treatment. If necessary, he or she can be admitted to an ICU with full code management. When the patient is approaching the end of life, on the other hand, treatment may be withheld. Given the complications, the probability of dying soon is high, but there remains hope in survival of the patient with the goal of restoring a satisfactory QOL in the short, medium and occasionally long term. As an example, patients admitted to ICU for respiratory distress with a do not intubate order may benefit from non-invasive methods of oxygenation or ventilation [4]. Finally, at the end-of-life stage, specific treatments are withdrawn, and the expected outcome is death of the patient. The priority is to ensure the best possible quality of dying in accordance with the patient's wishes, integrating support for family.

\section{More discriminating terminologies to clarify differing situations}

Different terms have been used to more closely correspond to the clinical condition of the palliative care patient: "comfort," "supportive," "best supportive care" or "hospice care" [5-7]. Whatever the term, confusion in terminology persists and no semantic consensus has 
been reached [8]. Heterogeneity is also found to characterize the end of life: "end-of-life," "terminal illness," "actively dying" and corresponding ways to treat the patient: "care of the dying," "terminal care," "transition of care," "quality-of-life care" [6]. Moreover, the implied duration of remaining life for end-of-life patients can range from a few days to 6 months, highlighting the confusion surrounding the ambiguities regarding the nature and intensity of the care to be provided.

Since up until now, no single word has been satisfactory, it is crucial to identify one or more words that can consensually clarify the patient's care pathways. The terminology should apply regardless of the pathology concerned.

\section{Distinction between the characterization of care and stage of the disease}

Care refers to a therapeutic objective that can be preventive or directly contribute to clinical improvement of the patient. Stage refers to the evolution of the disease according to various kinetics. The term palliative "care" can be applied to the patient without prejudging disease prognosis, whereas palliative "stage" corresponds to a pejorative prognosis for the patient.

\section{Lexical approach}

To overcome historical ambiguities and to improve description of a patient's course we propose new terms to refine the semiology of clinical situations. Firstly, we suggest the new word "pallitative" to characterize palliative care focused on end-of-life support. This neologism would apply to patients whose death is expected within a few days or a few weeks without any curative treatment or vital support treatment, and for whom comfort care at the end of life is a priority. The term "pallitative" can be considered as a lexical amalgam based on a common thematic sound; with this neologism, the general field of palliative care remains intact.

Secondly, we suggest the term "meliorative." Seldom used, it is opposed to "pejorative." It comes from the Latin meliorare, which means to improve, presenting the designated idea or object in a favorable light. It could be applied to the need to maintain the best possible QOL in situations where that is the objective. There is no longer any prospect of recovery or substantial expected improvement in the patient's condition. Patients benefit primarily from symptomatic treatment and care aimed at improving their immediate well-being.

In all clinical situations, the palliative care terminology remains intact, maintaining a global vision of the management of the seriously ill patient.

In summary, enriching the word "palliative" with semantic additions-including the word "meliorative" and the neologism "pallitative"-is proposed as a way of more precisely characterizing the nature of palliative care for the seriously ill (Table 1). This approach would be concordant with the physician orders for life-sustaining treatment (POLST) orders and facilitate preference concordance [9]. Such new proposals need to be discussed, validated and appropriated by the caregivers involved.

\section{Aknowledgements}

The authors wish to thank Jeffrey Arsham for reviewing and editing the original English-language manuscript.

\section{Authors' contributions \\ RR and MG have drafted the manuscript and approved the final submitted version. They have agreed both to be personally accountable for the author's own contributions and to ensure that questions related to the accuracy or integrity of any part of the work, even ones in which the author was not per- sonally involved, are appropriately investigated, resolved, and the resolution documented in the literature. \\ Funding \\ This research did not receive any specific grant from funding agencies in the public, commercial, or not-for-profit sectors.}

Availability of data and materials

Not applicable.

\section{Declarations}

Ethics approval and consent to participate

Not applicable.

Consent for publication

Not applicable.

Table 1 New proposals to characterize palliative management

\begin{tabular}{|c|c|c|c|c|}
\hline & Temporality & General condition physical abilities & Goals of Care & Admission in ICU \\
\hline Stage 1 Curative & $\begin{array}{l}\text { Extended life expectancy with good } \\
\text { expected quality of life }\end{array}$ & Preserved or can be standardized & Curative unlimited & Yes \\
\hline Stage 2 Meliorative & $\begin{array}{l}\text { Estimated end of life less than } \\
6 \text { months and altered quality of life }\end{array}$ & Altered & Sustaining quality of life & $\begin{array}{l}\text { No, or yes by with- } \\
\text { holding life sup- } \\
\text { port treatment }\end{array}$ \\
\hline Stage 3 Pallitative & $\begin{array}{l}\text { Entering the end of life; death } \\
\text { expected within a few days to a few } \\
\text { weeks }\end{array}$ & Deeply altered & End-of-life support & No \\
\hline
\end{tabular}




\section{Competing interest}

The authors declare that they have no competing interests.

\section{Author details}

'Service de Médecine Intensive Réanimation, University of Poitiers, CHU Poitiers France, CIC Inserm 1402 CHU, 86000 Poitiers, France. ${ }^{2}$ University of La Rochelle France, CNRS, 7266 LIENSs, La Rochelle, France.

Received: 1 June 2021 Accepted: 7 June 2021

Published online: 10 June 2021

\section{References}

1. Hui D, Bruera E. Models of integration of oncology and palliative care Ann Palliat Med. 2015;4:89-98. https://doi.org/10.3978/j.issn.2224-5820. 2015.04.01.

2. Allen LA, Stevenson LW, Grady KL, et al. Decision making in advanced heart failure: a scientific statement from the American Heart Association. Circulation. 2012;125:1928-52. https://doi.org/10.1161/CIR.0b013e3182 $4 \mathrm{f} 2173$

3. Temel JS, Greer JA, Muzikansky A, et al. Early palliative care for patients with metastatic non-small-cell lung cancer. N Engl J Med. 2010;363:73342. https://doi.org/10.1056/NEJMoa1000678.
4. Azoulay E, Kouatchet A, Jaber S, et al. Noninvasive mechanical ventilation in patients having declined tracheal intubation. Intensive Care Med. 2013;39:292-301. https://doi.org/10.1007/s00134-012-2746-2.

5. Fallon M, Smyth J. Terminology: the historical perspective, evolution and current usage-room for confusion? Eur J Cancer Oxf Engl. 2008;44:106971. https://doi.org/10.1016/j.ejca.2008.02.034.

6. Hui D, Nooruddin Z, Didwaniya N, et al. Concepts and definitions for "actively dying", "end of life", "terminally ill", "terminal care", and "transition of care": a systematic review. J Pain Symptom Manag. 2014;47:77-89. https://doi.org/10.1016/j.jpainsymman.2013.02.021.

7. Kelley AS, Morrison RS. Palliative Care for the Seriously III. N Engl J Med. 2015;373:747-55. https://doi.org/10.1056/NEJMra1404684.

8. Hui D, Bruera E. Integrating palliative care into the trajectory of cancer care. Nat Rev Clin Oncol. 2016;13:159-71. https://doi.org/10.1038/nrcli nonc.2015.201.

9. Hickman SE, Torke AM, Sachs GA, et al (2021) Factors associated with concordance between POLST orders and current treatment preferences. J Am Geriatr Soc jgs.17095. https://doi.org/10.1111/jgs.17095

\section{Publisher's Note}

Springer Nature remains neutral with regard to jurisdictional claims in published maps and institutional affiliations.
Ready to submit your research? Choose BMC and benefit from:

- fast, convenient online submission

- thorough peer review by experienced researchers in your field

- rapid publication on acceptance

- support for research data, including large and complex data types

- gold Open Access which fosters wider collaboration and increased citations

- maximum visibility for your research: over 100M website views per year

At BMC, research is always in progress.

Learn more biomedcentral.com/submissions 